\title{
GMR
}

\section{Presence of chromatoid bodies in the Rhodnius genus detected by cytochemical analysis}

\author{
K.C.C. Alevi ${ }^{1}$, N.F.C. Castro ${ }^{1}$, J. Oliveira ${ }^{2}$, J.A. Rosa ${ }^{2}$ and \\ M.T.V. Azeredo-Oliveira ${ }^{1}$ \\ ${ }^{1}$ Laboratório de Biologia Celular, Departamento de Ciências Biológicas, \\ Instituto de Biociências, Letras e Ciências Exatas, \\ Universidade Estadual Paulista “Júlio de Mesquita Filho", São José do Rio Preto, \\ SP, Brasil \\ ${ }^{2}$ Laboratório de Parasitologia, Departamento de Ciências Biológicas, \\ Faculdade de Ciências Farmacêuticas, \\ Universidade Estadual Paulista "Júlio de Mesquita Filho", Araraquara, SP, \\ Brasil \\ Corresponding author: K.C.C. Alevi \\ E-mail: kaiochaboli@hotmail.com \\ Genet. Mol. Res. 15 (2): gmr. 15027978 \\ Received November 4, 2015 \\ Accepted December 22, 2015 \\ Published April 25, 2016 \\ DOI http://dx.doi.org/10.4238/gmr.15027978
}

\begin{abstract}
In addition to the epidemiological importance regarding the transmission of Chagas disease, triatomines are also important biological models for cellular studies, because they have holocentric chromosomes, post-reductional meiosis for sex chromosomes, and nucleolar persistence. Although the nucleolus is present during spermiogenesis, it was suggested that it is inactivated and all transcriptional activity necessary for cell differentiation is supported by the chromatoid body (CB). Thus, considering the importance of $\mathrm{CB}$ to triatomine spermatogenesis, this paper aims to analyze the presence of this organelle in the Rhodnius genus. The testicles of five adult $R$. neglectus and $R$. prolixus males were analyzed after semi-
\end{abstract}


fine sections were performed, and the material was subjected to silver ion impregnation. The $\mathrm{CB}$ organelle was found in the spermatid of both species. Most CB studies focused on the Triatoma genus. This study described the existence of $\mathrm{CB}$ in Rhodnius, confirming thus the importance of this cytoplasmic organelle to spermiogenesis of these insect vectors of Chagas disease.

Key words: Chromatoid body; Nucleolus; Spermiogenesis

\section{INTRODUCTION}

In addition to the epidemiological importance regarding the transmission of Chagas disease, triatomines are also important biological models for cellular studies, because they have holocentric chromosomes with diffuse kinetochores. Moreover, these insects also exhibit unusual meiosis in which the segregation of sex chromosomes is post-reductional (Barth, 1956; Ueshima, 1966). In addition, these insects have a peculiar behavior regarding the nucleolus during spermatogenesis, which is termed nucleolar persistence (Tartarotti and Azeredo-Oliveira, 1999).

Nucleolar persistence is defined by the presence of the nucleolus or nucleolar corpuscles during meiotic metaphase, and it has currently been described in 25 triatomine species belonging to the Triatoma (Severi-Aguiar and Azeredo-Oliveira, 2005; Severi-Aguiar et al., 2006; MorielleSouza and Azeredo-Oliveira, 2007; Bardella et al., 2008; Costa et al., 2008; Alevi et al., 2013; Borgueti et al., 2015; Pereira et al., 2015), Rhodnius (Morielle and Azeredo-Oliveira, 2004; Morielle-Souza and Azeredo-Oliveira, 2007; Alevi et al., 2014a), Panstrongylus (Tartarotti and Azeredo-Oliveira, 1999), and Meccus genera (Madeira et al., 2016).

Although the nucleolus is present during triatomine spermiogenesis, transcriptional activity does not occur, because it is inactivated by epigenetic factors (Severi-Aguiar and Azeredo-Oliveira, 2005; Alevi et al., 2014b; Borgueti et al., 2015). Therefore, all transcriptional activity necessary for cell differentiation during spermiogenesis is supported by the chromatoid body (CB) (Alevi et al., 2014b, Borgueti et al., 2015).

The CB was discovered by von Brunn (1876) in the cytoplasm of white rat spermatids, and its functions include the "reserving" or "stocking" of RNA and proteins for various cell differentiation events that occur during spermiogenesis. Borguetti et al. (2015) suggested that this cytoplasmic organelle is formed during the triatomine nucleolar persistence phenomenon, and that it stores all RNA transcribed by persistent nucleolar material.

Most CB studies focused on the Triatoma genus (Silistino-Souza et al., 2012; Borgueti et al., 2015). Therefore, taking the importance of CB for triatomine spermatogenesis, this study aimed to analyze the presence of this organelle in Rhodnius.

\section{MATERIAL AND METHODS}

Five adult $R$. neglectus and $R$. prolixus males were provided by the "Insectarium of Triatominae" that was installed at the Faculty of Pharmaceutical Sciences, Campus de Araraquara, State of São Paulo, Brazil. The insects were anesthetized according to Alevi et al. (2015), and the testicles were dissected and dipped into a physiological solution of Demerec. The testicles were then exposed, and the seminiferous tubules were separated and fixed in 
Karnovsky solution, $\mathrm{pH}$ 7.4. The specimens were subsequently post-fixed with $1 \%$ osmium tetroxide before being dehydrated in acetone and embedded in Araldite resin. Semi-fine sections were made ( $0.5 \mathrm{~mm}$ thick), and the material was then subjected to silver ion impregnation (Howell and Black, 1980). Additional analysis and image capture were performed via light microscopy using a Zeiss Jenaval with an Axio Vision Rel 4.8 image analyzer.

\section{RESULTS AND DISCUSSION}

The CB organelle was found in the spermatids of both species (Figure 1, arrow). The $\mathrm{CB}$ is considered a macromolecular complex, which appears to have an important role in the coordination of post-transcriptional control of gene products in male haploid germ cells, and it also aids in determining messenger RNA destinations (Kotaja and Sassone-Corsi, 2007). Because of these characteristics, this structure has important functions associated with spermiogenesis, such as cellular communication between spermatids (Ventelä et al., 2003), mitochondrial targeting to the posterior region of spermatid nuclei (which assists in the formation of the mitochondrial sheath and the spermatozoid flagellum (Fawcett et al., 1970)), and the formation of the spermatozoid acrosome (Söderström and Parvinen, 1976; Tang et al., 1982).

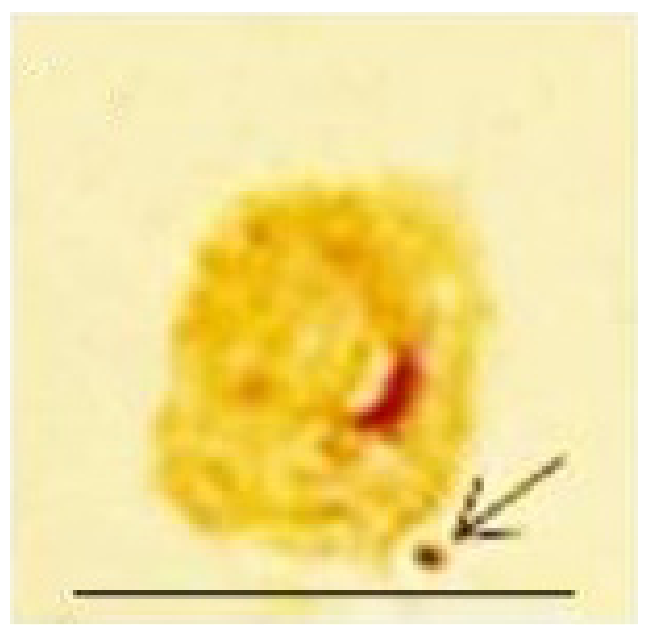

Figure 1. Semi-fine cuts of Rhodnius neglectus spermatids that were stained with silver ions. Note the presence of chromatoid body (arrow). Bar: $10 \mu \mathrm{m}$.

The origin of this cytoplasmic structure remains uncertain. Some authors support the idea that $\mathrm{CB}$ originates from a nuclear product that runs through the pore complex into the cytoplasm of cells (Parvinen and Parvinen, 1979; Parvinen et al., 1997). Other authors claim that CB originates from the accumulation of material from the inter-mitochondrial cytoplasm of spermatids (Fawcett et al., 1970) or from mitochondrial products that were released into the cytoplasm (Reunov et al., 2000). However, other authors believe that CB is a structure derived from fragmentation and migration of nucleolar material from the nucleus to the cytoplasm (Comings and Okada, 1972; Peruquetti and Azeredo-Oliveira, 2009; Peruquetti et al., 2008, 2010).

Silistino-Souza et al. (2012) examined the presence and formation of CB in $T$. infestans and T. sordida, and they confirmed the hypothesis that CB originated from nucleolar 
fragments. This conclusion was based on the results of immunocytochemical analyses where the presence of nucleolar fibrillarin protein was observed in the cytoplasmic organelle. On the other hand, Borgueti et al. (2015) suggested that the formation of CB in triatomines begins during spermatocytogenesis. Thus, the authors related the transcriptional activity during nucleolar persistence to the formation of $\mathrm{CB}$ and not to nucleolar fragments as suggested by Silistino-Souza et al. (2012).

Therefore, this study described the existence of CB in Rhodnius, confirming thus the importance of this cytoplasmic organelle to spermiogenesis of these insect vectors of Chagas disease.

\section{Conflicts of interest}

The authors declare no conflict of interest.

\section{ACKNOWLEDGMENTS}

Research supported by Fundação de Amparo à Pesquisa do Estado de São Paulo and Conselho Nacional de Desenvolvimento Científico e Tecnológico (CNPq).

\section{REFERENCES}

Alevi KCC, Mendonça PP, Pereira NP, Rosa JA, et al. (2013). Análise das Regiões Organizadoras Nucleolares e da atividade nucleolar em Triatoma melanocephala e T. lenti, importantes vetores da doença de Chagas. Rev. Ciênc. Farm. Basica Apl. 34: 417-421.

Alevi KCC, da Costa Castro NF, Lima ACC, Ravazi A, et al. (2014a). Nucleolar persistence during spermatogenesis of the genus Rhodnius (Hemiptera, Triatominae). Cell Biol. Int. 38: 977-980. http://dx.doi.org/10.1002/cbin.10297

Alevi KCC, Mendonça PP, Pereira NP, Rosa JA, et al. (2014b). Is there post-meiotic transcriptional activity during hemipteran spermiogene-sis? Inv. Rep. Dev. 58: 193-198. http://dx.doi.org/10.1080/07924259.2014.889767

Alevi KCC, Castro NFC, Oliveira J, Rosa JA, et al. (2015). Cystic spermatogenesis in three species of the prolixus complex (Hemiptera: Triatominae). Ital. J. Zool. (Modena) 82: 172-178.

Bardella VB, Azeredo-Oliveira MTV and Tartarotti E (2008). Cytogenetic analysis in the spermatogenesis of Triatoma melanosoma (Reduviidae; Heteroptera). Genet. Mol. Res. 7: 326-335. http://dx.doi.org/10.4238/vol7-2gmr411

Barth R (1956). Estudos anatômicos e histológicos sôbre a subfamília Triatominae (Hemiptera, Reduviidae). VI. Estudo comparativo sôbre a espermiocitogênese das espécies mais importantes. Mem. Inst. Oswaldo Cruz 54: 599-623. http://dx.doi.org/10.1590/S0074-02761956000300009

Borgueti AdeO, Alevi KCC, Silistino-Souza R, Rosa JA, et al. (2015). Immunofluorescence and ultrastructural analysis of the chromatoid body during spermatogenesis of Triatoma platensis and T. rubrovaria (Hemiptera, Triatominae). Micron 74: 44-46. http://dx.doi.org/10.1016/j.micron.2015.04.002

Comings DE and Okada TA (1972). The chromatoid body in mouse spermatogenesis: evidence that it may be formed by the extrusion of nucleolar components. J. Ultrastruct. Res. 39: 15-23. http://dx.doi.org/10.1016/S0022-5320(72)80003-0

Costa LC, Azeredo-Oliveira MTV and Tartarotti E (2008). Spermatogenesis and nucleolar activity in Triatoma klugi (Triatominae, Heteroptera). Genet. Mol. Biol. 31: 438-444. http://dx.doi.org/10.1590/S1415-47572008000300008

Fawcett DW, Eddy EM and Phillips DM (1970). Observations on the fine structure and relationships of the chromatoid body in mammalian spermatogenesis. Biol. Reprod. 2: 129-153. http://dx.doi.org/10.1095/biolreprod2.1.129

Howell WM and Black DA (1980). Controlled silver-staining of nucleolus organizer regions with a protective colloidal developer: a 1-step method. Experientia 36: 1014-1015. http://dx.doi.org/10.1007/BF01953855

Kotaja N and Sassone-Corsi P (2007). The chromatoid body: a germ-cell-specific RNA-processing centre. Nat. Rev. Mol. Cell Biol. 8: 85-90. http://dx.doi.org/10.1038/nrm2081

Madeira FF, Lima AAC, Rosa JA, Azeredo-Oliveira MTV, et al. (2016). Nucleolar persistence phenomenon during spermatogenesis in genus Meccus (Hemiptera, Triatominae). Genet. Mol. Res. 28: 15.

Morielle A and Azeredo-Oliveira MTV (2004). Description of the nucleolar activity and karyotype in germinative cell lines of Rhodnius domesticus (Triatominae, Heteroptera). Caryologia 57: 31-37. http://dx.doi.org/10.1080/000871 $\underline{14.2004 .10589369}$ 
Morielle-Souza A and Azeredo-Oliveira MTV (2007). Differential characterization of holocentric chromosomes in triatomines (Heteroptera, Triatominae) using different staining techniques and fluorescent in situ hybridization. Genet. Mol. Res. 6: 713-720.

Parvinen M and Parvinen LM (1979). Active movements of the chromatoid body. A possible transport mechanism for haploid gene products. J. Cell Biol. 80: 621-628. http://dx.doi.org/10.1083/jcb.80.3.621

Parvinen M, Salo J, Toivonen M, Nevalainen O, et al. (1997). Computer analysis of living cells: movements of the chromatoid body in early spermatids compared with its ultrastructure in snap-frozen preparations. Histochem. Cell Biol. 108: 77-81. http://dx.doi.org/10.1007/s004180050148

Pereira NP, Alevi KCC, Mendonça PP and Azeredo-Oliveira MTV (2015). Spermatogenesis and nucleolar behavior in Triatoma vandae and Triatoma williami (Hemiptera, Triatominae). Genet. Mol. Res. 14: 12145-12151. http://dx.doi. org/10.4238/2015.October.9.2

Peruquetti RL and Azeredo-Oliveira (2009). Characterization of the nucleolar cycle and chromatoid body formation in the spermatogenesis of some vertebrate species. Genet. Mol. Res. 8: 456-457. http://dx.doi.org/10.4238/vol8-2TA017

Peruquetti RL, Assis IM, Taboga SR and de Azeredo-Oliveira MT (2008). Meiotic nucleolar cycle and chromatoid body formation during the rat (Rattus novergicus) and mouse (Mus musculus) spermiogenesis. Micron 39: 419-425. http:// dx.doi.org/10.1016/j.micron.2007.02.009

Peruquetti RL, Taboga SR and de Azeredo-Oliveira MT (2010). Characterization of Mongolian gerbil chromatoid bodies and their correlation with nucleolar cycle during spermatogenesis. Reprod. Domest. Anim. 45: 399-406. http://dx.doi. org/10.1111/j.1439-0531.2008.01204.x

Reunov A, Isaeva V, Au D and Wu R (2000). Nuage constituents arising from mitochondria: is it possible? Dev. Growth Differ. 42: 139-143. http://dx.doi.org/10.1046/j.1440-169x.2000.00492.x

Severi-Aguiar GDC and Azeredo-Oliveira MTV (2005). Cytogenetic study on three species of the genus Triatoma (Heteroptera:Reduviidae) with emphasis on nucleolar organizer regions. Caryologi 58: 293-299. http://dx.doi.org/1 $\underline{0.1080 / 00087114.2005 .10589466}$

Severi-Aguiar GDC, Lourenço LB, Bicudo HEMC and Azeredo-Oliveira MTV (2006). Meiosis aspects and nucleolar activity in Triatoma vitticeps (Triatominae, Heteroptera). Genetica 126: 141-151. http://dx.doi.org/10.1007/s10709$\underline{005-1443-2}$

Silistino-Souza R, Peruquetti RL, Taboga SR and Vilela de Azeredo-Oliveira MT (2012). Chromatoid body: remnants of nucleolar proteins during spermatogenesis in triatomine (Heteroptera, Triatominae). Micron 43: 954-960. http:// dx.doi.org/10.1016/j.micron.2012.03.017

Söderström KO and Parvinen M (1976). Transport of material between the nucleus, the chromatoid body and the Golgi complex in the early spermatids of the rat. Cell Tissue Res. 168: 335-342. http://dx.doi.org/10.1007/BF00215311

Tang XM, Lalli MF and Clermont Y (1982). A cytochemical study of the Golgi apparatus of the spermatid during spermiogenesis in the rat. Am. J. Anat. 163: 283-294. http://dx.doi.org/10.1002/aja.1001630402

Tartarotti E and Azeredo-Oliveira MTV (1999). Patterns of nucleolar activity during spermatogenesis of two triatomines, Panstrongylus megistus and P. herreri. Caryologia 52: 177-184. http://dx.doi.org/10.1080/00087114.1998.10589171

Ueshima N (1966). Cytotaxonomy of the triatominae (Reduviidae: Hemiptera). Chromosoma 18: 97-122. http://dx.doi. org/10.1007/BF00326447

Ventelä S, Toppari J and Parvinen M (2003). Intercellular organelle traffic through cytoplasmic bridges in early spermatids of the rat: mechanisms of haploid gene product sharing. Mol. Biol. Cell 14: 2768-2780. http://dx.doi.org/10.1091/ mbc.E02-10-0647

von Brunn A (1876). Beiträge zur Entwicklungsgeschichte der Samenkörper. Arch. Mikrosk. Anat. 12: 528-536. http:// dx.doi.org/10.1007/BF02933904 